\title{
Muscadine Grape Skin Extract
}

National Cancer Institute

\section{Source}

National Cancer Institute. Muscadine Grape Skin Extract. NCI Thesaurus. Code $C 96231$.

A nutritional supplement containing an extract of the skin of Muscadine grape (Vitis rotundifolia), with anti-inflammatory, antioxidant and potential chemopreventive activities. The skin extract of the muscadine grape contains numerous phytochemicals including hydrolyzable tannins and flavonoids, such as anthocyanin 3,5-diglucosides, quercetin, myricetin, and kaempferol glycosides. Upon administration, muscadine grape skin extract (MSKE) appears to inhibit PI3K/Akt and MAPK signaling, eventually leading to apoptosis and a reduction in tumor cell proliferation. 